\title{
Total Aortic Arch Replacement: Case Report of the first successful total arch replacement in Nepal and Review of contemporary techniques in arch surgery
}

\author{
Rabindra Timala ${ }^{1}$, Ashish Amatya ${ }^{2}$, Nishes Basnet ${ }^{1}$, Rupak Pradhan ${ }^{1}$, Dikshya Joshi ${ }^{1}$, \\ Marisha Aryal ${ }^{1}$, Navin Gautam ${ }^{1}$
}

${ }^{1}$ Department of Cardiac Surgery, Shahid Gangalal National Heart Center, Kathmandu, Nepal

${ }^{2}$ Department of Anaesthesia, Shahid Gangalal National Heart Center, Kathmandu, Nepal

Corresponding Author: Rabindra Timala

Department of Cardiac Surgery, Shahid Gangalal National Heart Center, Kathmandu, Nepal

Email: rabindratimala@gmail.com

ORCID ID NO: 0000-002-4907-4743

Cite this article as: Timala R., Amatya A., Basnet N., et al. Total Aortic Arch Replacement: Case Report of the first successful total arch replacement in Nepal and Review of contemporary techniques in arch surgery. Nepalese Heart Journal 2021; Vol 18(2), 73-76.

Submission date: $25^{\text {th }}$ July, 2021

Accepted date: $20^{\text {th }}$ September, 2021

\section{Abstract}

Aortic arch replacement is formidable cardiac surgery that is fraught with complications like brain injury, coagulopathy along with high mortality. Over the past several years, various techniques like deep hypothermic circulatory arrest, retrograde cerebral perfusion, and selective antegrade cerebral perfusion along with branched graft techniques have been developed with better early outcomes. We share our experience of successful replacement of ascending and total aortic arch in a 60 years old female, who presented with ascending and aortic arch aneurysm.

Keywords: Deep hypothermic circulatory arrest, Retrograde cerebral perfusion, Selective antegrade cerebral perfusion, Branched aortic graft, Total aortic arch replacement

DOI: https://doi.org/10.3126/njh.v18i2.40411

\section{Introduction}

Aortic arch replacement is one of the most challenging operations in cardiovascular surgery. Surgery involves interrupting blood supply to brain, which is the most oxygen dependent organ in the body. Traditionally, surgery has been carried out, by subjecting profound hypothermia $\left(18-20^{\circ} \mathrm{C}\right)$, to reduce metabolic demands, along with surgical haste to minimize cerebral ischemia time. Later on techniques of cerebral perfusion (antegrade or retrograde) has been added to increase the safety of the procedure. Graft modifications include using branched graft instead of single tubular graft for technical simplicity and dissociation of brain and rest of the body regarding circulation.

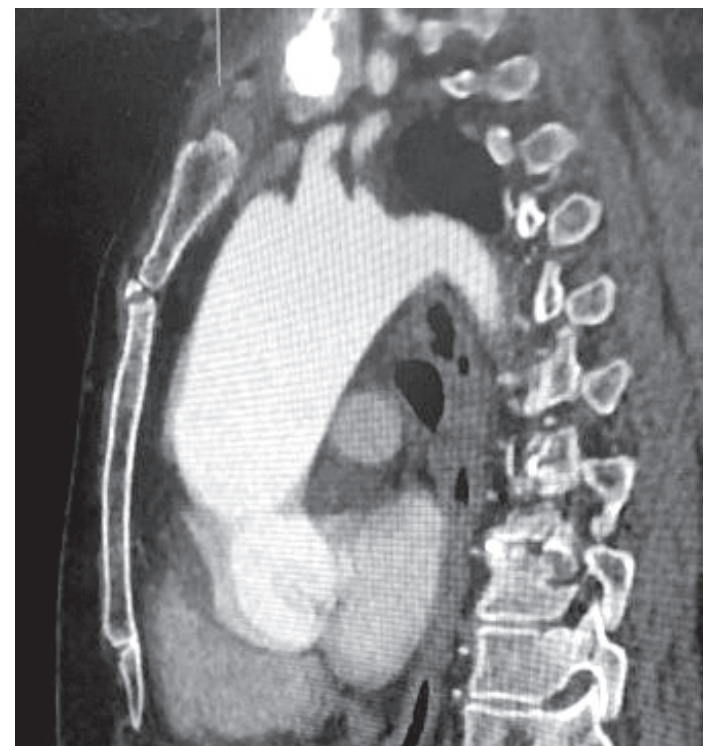

Figure 1: CT Angiogram 

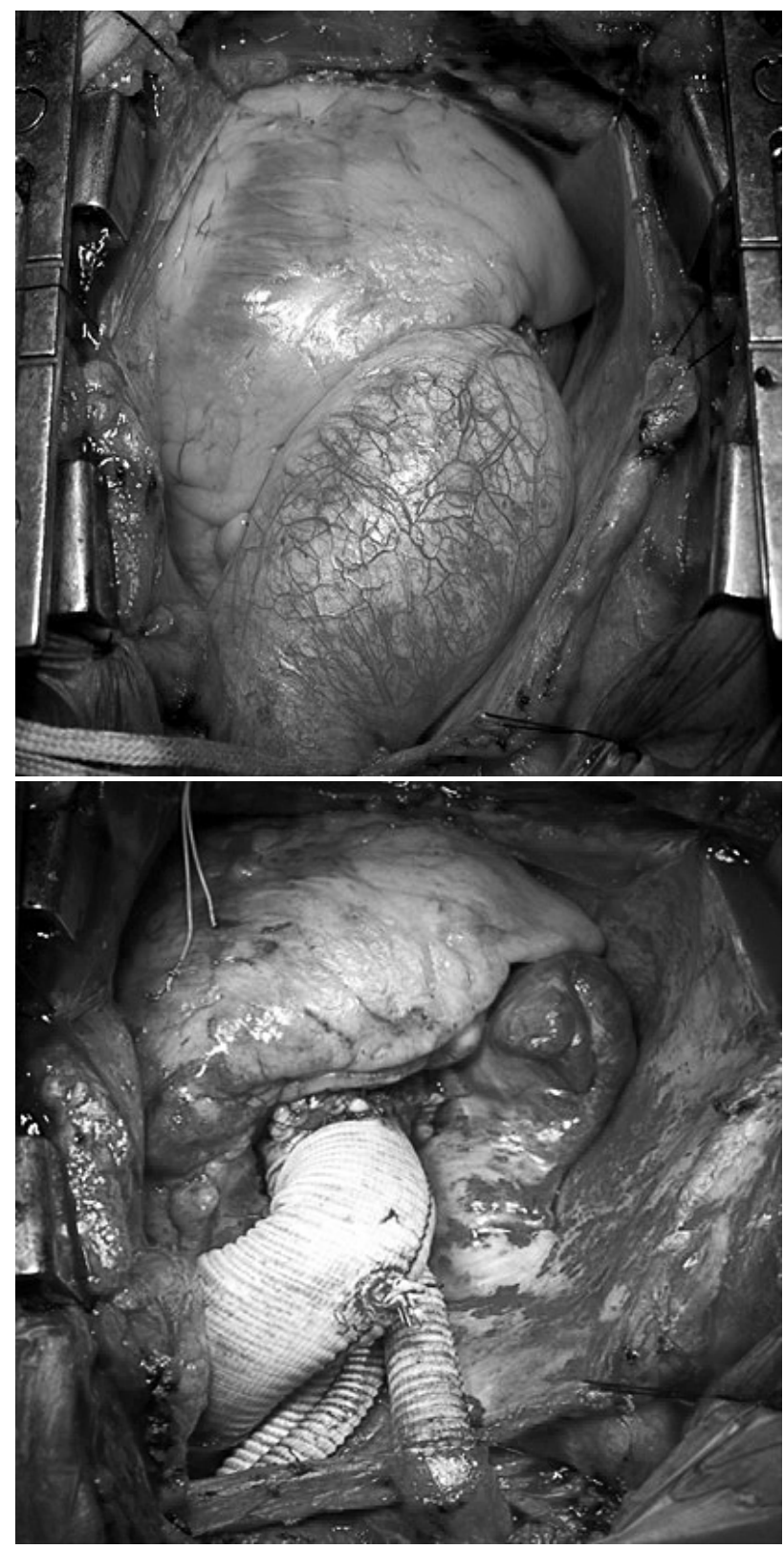

Figure 2: Intraoperative Images

\section{Case Report}

Sixty years old female diagnosed with bicuspid aortic valve, ascending and arch aneurysm presented with palpitation for 5 months along with lower limb swelling for 2 years prior to admission. Echocardiogram showed bicuspid aortic valve, with mild aortic stenosis (peak gradient: $25 \mathrm{mmHg}$; mean gradient: $13 \mathrm{mmHg}$ ), mild aortic regurgitation. Left ventricular dimensions in diastole was $5.4 \mathrm{~cm}$ and in systole was $3.4 \mathrm{~cm}$. Her ejection fraction was $55 \%$. CT scan showed ascending aorta (max. dimension) as $6.7 \times 6.1$ $\mathrm{cm}$, sinotubular junction $3.7 \mathrm{~cm}$, mid aortic arch $5.7 \mathrm{~cm}$. (Figure 1). Patient was taken for surgery on 29/ 9/2075 B.S (January 13, 2019 $\mathrm{AD}$ ). The intraoperative images are shown below. (Figure 2)

Right femoral artery and bicaval cannulation was done. Patient was cooled down to $25^{\circ} \mathrm{C}$. Dacron graft $(8 \mathrm{~mm})$ was sutured to innominate artery and blood was pumped through separate roller pump into the innominate artery. Innominate artery was divided proximal to the graft, arch end was sutured; left carotid artery was divided and separate cannula was used for selective antegrade cerebral perfusion into the left common carotid artery. Meanwhile heart started to fibrillate due to hypothermia, so cross clamp was applied and antegrade cardioplegia given. Aortotomy was done and osteal cardioplegia was given.

Left subclavian artery was then divided. Proximal descending aorta clamped and femoral perfusion continued along with selective antegrade cerebral perfusion (SACP) throughout the procedure. Ascending aorta from sinotubular junction to aortic arch, just distal to the origin of left subclavian artery was excised. Dacron graft (24mm), with 4 branches, was anastomosed distally to descending aorta and proximally to sinotubular junction. After proper de-airing, cross clamp was removed. Fourth branch of the graft was used for lower body perfusion, stopping femoral perfusion. Left common carotid artery and innominate artery were anastomosed to graft, providing flow to the brain through the main graft. Subclavian artery was finally anastomosed to graft branch.

Total cardiopulmonary bypass time was 243 minutes and aortic cross clamp time was 133 minutes and antegrade cerebral perfusion time was 138 minutes. Chest wall closed primarily.

Post operatively patient required very minimal amount of inotropic support and was extubated next morning. She was discharged home on 7th post-operative day. She has been on regular follow up and her status has been unremarkable.

\section{Discussion}

Aortic arch surgery has been associated with high rates of morbidity and mortality. Traditional surgery involves interrupting cerebral blood flow, necessitating the use of strategies to protect brain in the process. Deep hypothermic circulatory arrest (HCA) was developed as an adjunct for aortic arch surgery in 1975 by Griepp et al. ${ }^{1}$. A primary disadvantage of using deep hypothermic circulatory arrest is the prolonged bypass times required for cooling and rewarming which adds significantly to the morbidity associated with these procedures, especially coagulopathy-related bleeding ${ }^{2,3}$, organ dysfunction like stroke and death ${ }^{4-6}$. Therefore, HCA is normally performed with the use of retrograde cerebral perfusion (RCP) or selective antegrade cerebral perfusion (SACP).

Ueda first reported using retrograde cerebral perfusion (RCP) in conjunction with deep hypothermic circulatory arrest (HCA) during ascending and transverse arch repairs ${ }^{7,8}$. This has been widely adopted for prevention of cerebral ischemia during the operative treatment of aortic arch aneurysm along with profound hypothermic circulatory arrest by various groups ${ }^{9-11}$. In most centers, flow is adjusted to maintain pressure in the range of 15 to $25 \mathrm{~mm} \mathrm{Hg}$ with monitoring via either catheter in superior vena cava or a jugular bulb catheter ${ }^{12}$.

Bachet et al described the technique of SACP with cold blood during surgery of the aortic arch in $1986^{13}$. It avoids the use of deep hypothermia, prolonged cardiopulmonary bypass with no time bound to perform the aortic repair. SACP is initiated with flow of $10 \mathrm{ml} / \mathrm{kg} / \mathrm{min}$ after occluding innominate artery ${ }^{13}$. As most patients have complete 'circle of Willis', right-sided SACP generally provide adequate left sided cerebral protection. When direct left-sided SACP is indicated, it can be delivered through the left common carotid artery by inserting a balloon-tipped catheter that has been connected to a Y-limb from the arterial CPB line. Tanaka et al described SACP with three-vessel cannulation using bilateral axillary cannulation with temperature maintained below $25^{\circ} \mathrm{C}^{14}$. With continuous SACP, surgery can be done at much warmer temperature as opposed to $18^{\circ} \mathrm{C}$. Warmer temperature can reduce coagulopathy; can result in shorter bypass time, shorter length of hospital stay and lower early mortality; prevent development of lung injury and other transfusion related sequelae ${ }^{15}$. The optimal temperature in the setting of antegrade SACP seems to be between $20^{\circ} \mathrm{C}$ and $28^{\circ} \mathrm{C}^{13,16,17}$. Quan $\mathrm{Li}$ et al published their case report on 4 patients with type A aortic dissection, on whom they replaced total aortic arch, along with 
frozen elephant trunk of proximal descending thoracic aorta with the help of 4-branched graft at a core temperature of $34^{\circ} \mathrm{C}^{18}$.

In an experimental study by Sakurada et al, cerebral protection efficacy of HCA, RCP, and SACP were compared and found that SACP was the safest method for arch reconstruction that requires a cerebral protection period of 90 minutes $^{19}$. Kazui et al found SACP to be physiologically superior to HCA and RCP because it supplies sufficient oxygenated blood to the brain in an antegrade direction and therefore can be used to protect the brain for an unlimited time ${ }^{20}$.

Hazim Saafi et al reported using RCP in 907 (82\%) among 1107 cases of ascending and transverse aortic arch replacement ${ }^{21}$. They reported stroke rate of $2.8 \%$, which compared favorably with other contemporary series reporting stroke incidences from $3 \%$ to $12 \%$ regardless of technique of cerebral perfusion ${ }^{7,22,23}$. Although Hazim Saafi et al acknowledged that adequate nutritive flow might not be provided by RCP, they concluded that the use of RCP with profound hypothermic circulatory arrest is associated with a reduction in mortality and stroke. Other reported benefits include flushing of atheromatous debris and uniform cerebral cooling $g^{10,24,25}$.

\section{Dealing with brachiocephalic vessels}

Traditionally, cuff of aortic tissue containing brachiocephalic vessels "island technique" was used to sew these vessels to the graft. It has disadvantage of improper hemostasis, especially on the posterior side. The aortic tissue left behind is often affected by atherosclerosis and might become aneurysmal later on, especially among patients with connective tissue disorder ${ }^{26}$.

Branched graft technique developed by Spielvogel and colleagues simplifies the management of brachiocephalic vessels and provide safe access for providing continuous $\mathrm{SACP}^{27}$. Without interrupting blood supply to brain or with brief interruption, surgeon can anastomose all three brachiocephalic vessels to graft branches with easier access to suture line in case of bleeding. Further advantages includes shorter total pump and SACP times than those necessary in en bloc repair ${ }^{28}$; atherosclerotic lesions that frequently develop near the origin of arch vessels can be completely resected; anastomosis of arch vessels in area not affected by dissection ${ }^{20}$.

\section{Neurologic outcome}

Neurologic deficit can be temporary neurologic deficit or stroke. A prospective comparative study by Okita et $\mathrm{al}^{29}$ confirmed that SACP significantly reduced the prevalence of temporary neurologic dysfunction compared with retrograde cerebral perfusion. The incidence of stroke in studies that used HCA ranged from 0 to $11 \%^{1,6,30}$, RCP 0 to about $12 . \%^{7,9-11}$ and SCP 0 to about $5.4 \%^{20,31-34}$.

Preoperative factors such as pre-operative stroke and presence of occlusive arterial disease can influence the incidence of postoperative stroke34. Svensson and colleagues also reported a high incidence of stroke after operation under HCA in patients with a history of cerebrovascular disease. Therefore, in patients with old cerebral infarcts, further improvement in brain protection methods will be necessary ${ }^{6}$.

\section{Neurological monitoring}

Conventional intraoperative monitoring for example electrocardiography (ECG), pulse oximetry, end tidal carbon dioxide and non-invasive blood pressure, gives little indication of the adequacy of oxygen delivery (DO2) to the patient during surgery.

Near-infrared spectroscopy (NIRS) is a continuous, realtime, non-invasive cerebral oximetry that allows detection of brain ischaemia. It provides regional cortical saturation ( $\mathrm{rSO} 2)$, a reflection of the balance between oxygen delivery and utilization in a given region and has been shown to correlate well with jugular venous bulb saturation and brain tissue oxygen pressure ${ }^{36}$. Clinical studies suggest that it is reliable in detecting perioperative cerebral oxygen desaturation events, especially in cardiac surgery, although clinical benefits remain to be proven ${ }^{37}$.

\section{Mortality Rates}

Historically, aortic arch surgery has been associated with high mortality. Studies show mortality between 10 to $15 \%$ in studies using HCA6,30, and $6.7 \%$ in study using HCA or RCP9, $17.7 \%$ with SACP and branched graft ${ }^{20}$. However, contemporary studies of Aortic arch surgery with SACP reports early mortality rate from $3.4 \%$ to $8.2 \% 0^{38-40}$

\section{Conclusion}

Hypothermic circulatory arrest along with retrograde and selective antegrade cerebral perfusion provides effective form of cerebral protection. Along with cerebral circulatory adjunct, branched graft technique simplifies aortic arch replacement while removing the need for deep hypothermia, circulatory arrest, extended periods of cardiopulmonary bypass and time pressure on the surgeon.

\section{References}

1. Griepp RB, Stinson EB, Hollingsworth JF, Buehler D. Prosthetic replacement of the aortic arch. J Thorac Cardiovasc Surg. 1975 Dec;70(6):1051-63.

2. Reed RL, Bracey AW, Hudson JD, Miller TA, Fischer RP. Hypothermia and blood coagulation: dissociation between enzyme activity and clotting factor levels. Circ Shock. 1990 Oct;32(2):141-52.

3. Mora Mangano CT, Neville MJ, Hsu PH, Mignea I, King J, Miller DC. Aprotinin, Blood Loss, and Renal Dysfunction in Deep Hypothermic Circulatory Arrest. Circulation. 2001 Sep 18;104(suppl 1). DOI: 10.1161/hc37t1.094702

4. Mezrow CK, Midulla PS, Sadeghi AM, Gandsas A, Wang W, Dapunt OE, et al. Evaluation of cerebral metabolism and quantitative electroencephalography after hypothermic circulatory arrest and low-flow cardiopulmonary bypass at different temperatures. J Thorac Cardiovasc Surg. 1994 Apr;107(4).

5. Hagl C, Ergin MA, Galla JD, Lansman SL, McCullough JN, Spielvogel D, et al. Neurologic outcome after ascending aortaaortic arch operations: Effect of brain protection technique in high-risk patients. J Thorac Cardiovasc Surg. 2001 Jun;121(6). DOI:10.1067/mtc.2001.113179

6. Svensson LG, Crawford ES, Hess KR, Coselli JS, Raskin S, Shenaq SA, et al. Deep hypothermia with circulatory arrest. Determinants of stroke and early mortality in 656 patients. $\mathrm{J}$ Thorac Cardiovasc Surg. 1993 Jul;106(1).

7. Ueda Y, Miki S, Kusuhara K, Okita Y, Tahata T, Yamanaka $\mathrm{K}$. Surgical treatment of aneurysm or dissection involving the ascending aorta and aortic arch, utilizing circulatory arrest and retrograde cerebral perfusion. J Cardiovasc Surg (Torino). 31(5).

8. Ueda Y, Miki S, Kusuhara K, Okita Y, Tahata T, Yamanaka $\mathrm{K}$. Deep hypothermic systemic circulatory arrest and continuous retrograde cerebral perfusion for surgery of aortic arch aneurysm. Eur J Cardio-Thoracic Surg. 1992;6(1). DOI:10.1016/1010-7940(92)90096-G

9. Coselli JS, Büket S, Djukanovic B. Aortic arch operation: Current treatment and results. Ann Thorac Surg. 1995 Jan;59(1). DOI:10.1016/0003-4975(94)00812-L

10. Deeb GM, Jenkins E, Bolling SF, Brunsting LA, Williams DM, Quint LE, et al. Retrograde cerebral perfusion during hypothermic circulatory arrest reduces neurologic morbidity. J Thorac Cardiovasc Surg. 1995 Feb;109(2). DOI:10.1016/ S0022-5223(95)70387-X

11. Okita Y, Takamoto S, Ando M, Morota T, Matsukawa R, Kawashima Y. Mortality And Cerebral Outcome In Patients Who Underwent Aortic Arch Operations Using Deep Hypothermic Circulatory Arrest With Retrograde Cerebral 
Perfusion: No Relation Of Early Death, Stroke, And Delirium To The Duration Of Circulatory Arrest. J Thorac Cardiovasc Surg. 1998 Jan;115(1). DOI: 10.1016/S0022-5223(98)70451-9

12. Reich DL, Uysal S, Ergin MA, Griepp RB. Retrograde cerebral perfusion as a method of neuroprotection during thoracic aortic surgery. Ann Thorac Surg. 2001 Nov;72(5). DOI: $10.1016 / \mathrm{S} 0003-4975(01) 02718-7$

13. Bachet J, Guilmet D, Goudot B, Dreyfus GD, Delentdecker $\mathrm{P}$, Brodaty D, et al. Antegrade cerebral perfusion with cold blood: a 13-year experience. Ann Thorac Surg. 1999 Jun;67(6).DOI: 10.1016/S0003-4975(99)00411-7

14. Tanaka Y, Mikamo A, Suzuki R, Kurazumi H, Kudo T, Takahashi M, et al. Mortality and Morbidity After Total Aortic Arch Replacement. Ann Thorac Surg. 2014 May;97(5).DOI: 10.1016/j.athoracsur.2014.01.014

15. Matalanis G, Koirala RS, Shi WY, Hayward PA, McCall PR. Branch-first aortic arch replacement with no circulatory arrest or deep hypothermia. J Thorac Cardiovasc Surg. 2011 Oct;142(4).DOI: 10.1016/j.jtcvs.2011.01.020

16. Kazui T, Yamashita K, Washiyama N, Terada H, Bashar AHM, Suzuki K, et al. Aortic Arch Replacement Using Selective Cerebral Perfusion. Ann Thorac Surg. 2007 Feb;83(2).DOI: 10.1016/j.athoracsur.2006.10.082

17. Minatoya K, Ogino H, Matsuda H, Sasaki H, Tanaka H, Kobayashi J, et al. Evolving Selective Cerebral Perfusion for Aortic Arch Replacement: High Flow Rate With Moderate Hypothermic Circulatory Arrest. Ann Thorac Surg. 2008 Dec;86(6).DOI: 10.1016/j.athoracsur.2008.07.024

18. Li Q, Qu H, Liu T, Yu J, Lv M. Total aortic arch replacement surgery with a Core temperature of $34^{\circ} \mathrm{C}$. J Cardiothorac Surg. 2019 Dec 4;14(1).DOI: 10.1186/s13019-019-1001-0

19. Sakurada T, Kazui T, Tanaka H, Komatsu S. Comparative experimental study of cerebral protection during aortic arch reconstruction. Ann Thorac Surg. 1996 May;61(5).DOI: 10.1016/0003-4975(96)00026-4

20. Kazui T, Washiyama N, Muhammad BA., Terada H, Yamashita K, Takinami M, et al. Total arch replacement using aortic arch branched grafts with the aid of antegrade selective cerebral perfusion. Ann Thorac Surg. 2000 Jul;70(1).DOI: 10.1016/S0003-4975(00)01535-6

21. Estrera AL, Miller CC, Lee T-Y, Shah P, Safi HJ. Ascending and Transverse Aortic Arch Repair. Circulation. 2008 Sep 30;118(14_suppl_1).DOI: 10.1161/ CIRCULATIONAHA.107.757419

22. Moon MR, Sundt TM. Influence of retrograde cerebral perfusion during aortic arch procedures. Ann Thorac Surg. 2002 Aug;74(2).DOI 10.1016/S0003-4975(02)03724-4

23. Matalanis G, Hata M, Buxton BF. A retrospective comparative study of deep hypothermic circulatory arrest, retrograde, and antegrade cerebral perfusion in aortic arch surgery. Ann Thorac Cardiovasc Surg. 2003 Jun;9(3).

24. Ehrlich MP, Fang WC, Grabenwöger M, Kocher A, Ankersmit J, Laufer G, et al. Impact of retrograde cerebral perfusion on aortic arch aneurysm repair. J Thorac Cardiovasc Surg. 1999 Dec;118(6).DOI: 10.1016/S0022-5223(99)70097-8

25. Safi HJ, Letsou G V, Iliopoulos DC, Subramaniam MMH, Miller CC, Hassoun MH, et al. Impact of Retrograde Cerebral Perfusion on Ascending Aortic and Arch Aneurysm Repair. Ann Thorac Surg. 1997 Jun;63(6).DOI: 10.1016/S00034975(97)00296-8

26. Svensson LG, Crawford ES. Cardiovascular and Vascular Disease of the Aorta . 1st ed. Philadelphia: W.B. Saunders Co.; 1957. 97-100 p.

27. Spielvogel D, Strauch JT, Minanov OP, Lansman SL, Griepp RB. Aortic arch replacement using a trifurcated graft and selective cerebral antegrade perfusion. Ann Thorac Surg. 2002 Nov;74(5). DOI: 10.1016/S0003-4975(02)04156-5
28. Kazui T, Kimura N, Yamada O, Komatsu S. Total arch graft replacement in patients with acute type a aortic dissection. Ann Thorac Surg. 1994 Nov;58(5).DOI: 10.1016/00034975(94)91936-4

29. Okita Y, Minatoya K, Tagusari O, Ando M, Nagatsuka K, Kitamura S. Prospective comparative study of brain protection in total aortic arch replacement: deep hypothermic circulatory arrest with retrograde cerebral perfusion or selective antegrade cerebral perfusion. Ann Thorac Surg. 2001 Jul;72(1).DOI: 10.1016/S0003-4975(01)02671-6

30. Ergin MA, Galla JD, Lansman s L, Quintana C, Bodian C, Griepp RB. Hypothermic circulatory arrest in operations on the thoracic aorta. Determinants of operative mortality and neurologic outcome. J Thorac Cardiovasc Surg. 1994 Mar;107(3).

31. Dossche KM, Schepens MAA., Morshuis WJ, Muysoms FE, Langemeijer JJ, Vermeulen FE. Antegrade selective cerebral perfusion in operations on the proximal thoracic aorta. Ann Thorac Surg. 1999 Jun;67(6).DOI: 10.1016/S00034975(99)00416-6

32. Veeragandham RS, Hamilton IN, O'Connor C, Rizzo V, Najafi H. Experience with antegrade bihemispheric cerebral perfusion in aortic arch operations. Ann Thorac Surg. 1998 Aug;66(2).DOI: 10.1016/S0003-4975(98)00452-4

33. Kazui T, Inoue N, Yamada O, Komatsu S. Selective cerebral perfusion during operation for aneurysms of the aortic arch: A reassessment. Ann Thorac Surg. 1992 Jan;53(1).DOI: 10.1016/0003-4975(92)90767-X

34. Bachet J, Guilmet D, Goudot B, Termignon JL, Teodori G, Dreyfus G, et al. Cold cerebroplegia. A new technique of cerebral protection during operations on the transverse aortic arch. J Thorac Cardiovasc Surg. 1991 Jul;102(1).

35. Ohmi M, Tabayashi K, Hata M, Yokoyama H, Sadahiro M, Saito H. Brain damage after aortic arch repair using selective cerebral perfusion. Ann Thorac Surg. 1998 Oct;66(4).DOI: 10.1016/S0003-4975(98)00587-6

36. Smith M. Shedding light on the adult brain: a review of the clinical applications of near-infrared spectroscopy. Philos Trans R Soc A Math Phys Eng Sci. 2011 Nov 28;369(1955). DOI: 10.1098/rsta.2011.0242

37. Serraino GF, Murphy GJ. Effects of cerebral near-infrared spectroscopy on the outcome of patients undergoing cardiac surgery: a systematic review of randomised trials. BMJ Open. 2017 Sep 7;7(9).DOI: 10.1136/bmjopen-2017-016613

38. Numata S, Tsutsumi Y, Monta O, Yamazaki S, Seo H, Sugita R, et al. Aortic Arch Repair With Antegrade Selective Cerebral Perfusion Using Mild to Moderate Hypothermia of More Than $28^{\circ}$ C. Ann Thorac Surg. 2012 Jul;94(1).DOI: 10.1016/j. athoracsur.2012.03.055

39. Okada K, Omura A, Kano H, Sakamoto T, Tanaka A, Inoue T, et al. Recent advancements of total aortic arch replacement. J Thorac Cardiovasc Surg. 2012 Jul;144(1).DOI: 10.1016/j. jtcvs.2011.08.039

40. Krähenbühl ES, Immer FF, Stalder M, Englberger L, Eckstein FS, Schmidli J, et al. Technical advances improved outcome in patients undergoing surgery of the ascending aorta and/or aortic arch: ten years experience. Eur J Cardio-Thoracic Surg. 2008 Sep;34(3). DOI:10.1016/j.ejcts.2008.04.051 